Avalaible online: https://ejournal.iai-tribakti.ac.id/index.php/pgmı

Article doi: https://doi.org/10.33367/jiee.v3i1.1541

Submission: 2021-1-26 Review: 2021-2-11 Revision: 2021-2-18 Accepted: 2021-03-09

\title{
PENERAPAN METODE BERCERITA DALAM MENINGKATKAN \\ PERKEMBANGAN SOSIAL EMOSIONAL ANAK USIA DINI \\ DI RAUDLATUL ATHFAL IHYAUL ISLAM \\ PRASI GADING
}

\section{APPLICATION OF STORY METHODS IN IMPROVING THE SOCIAL EMOTIONAL DEVELOPMENT OF EARLY CHILDREN IN RAUDLATUL ATHFALIHYAUL ISLAM PRASI GADING}

\author{
Terza Travelancya ${ }^{1}$ \\ 1 Universitas Islam Zainul Hasan Genggong \\ 1travelancya@gmail.com
}

\begin{abstract}
The storytelling method is one of providing learning experiences for RA children by verbally telling stories to children. Storytelling is the process of introducing emotional forms and expressions to children, such as anger, sadness, joy, annoyance, and humor. This method is implemented because the objects to be studied are using story books. This research took place at RA Ihyaul Islam Prasi Gading. The purpose of this study was to determine how the teacher's storytelling method was applied in improving children's social emotional development. The research subjects were 2 teachers and 19 students, while the object of the research was the application of the teacher in improving children's social emotional development through storytelling methods. The approach used was descriptive qualitative. Data collection techniques used were observation, interviews, and documentation. The results showed that the social emotional development of children could not develop optimally.The development indicators are expressing emotions in accordance with existing conditions, recognizing manners and manners according to local socio-cultural values, understanding regulations and discipline. The indicator points are controlling emotions in a reasonable way, giving and returning greetings, obeying the rules of the game.
\end{abstract}

Key Word: Oratory skills, Storytelling method, Social emotional development

\begin{abstract}
Abstrak
Metode bercerita adalah salah satu pemberian pengalaman belajar bagi anak RA dengan membawakan cerita kepada anak secara lisan. bercerita merupakan proses mengenalkan bentuk-bentuk emosi dan ekspresi kepada anak, misalnya marah, sedih, gembira, kesal, dan lucu. Metode ini dilaksanakan karena obyek yang akan dipelajari menggunakan buku cerita. Penelitian ini bertempat di RA Ihyaul Islam Prasi Gading. Tujuan penelitian
\end{abstract}


ini adalah untuk mengetahui bagaimana penerapan metode bercerita yang dilakukan guru dalam meningkatkan perkembangan sosial emosional anak. Subjek penelitian adalah 2 orang guru dan 19 anak didik, sedangkan objek penelitiannya adalah penerapan guru dalam meningkatkan perkembangan sosial emosional anak melalui metode bercerita.Pendekatan yang digunakan adalah deskriptif kualitatif. Teknik pengumpulan data yang digunakan adalah observasi, wawancara, dan dokumentasi. Hasil penelitian menunjukkan bahwa perkembangan sosial emosional anak belum dapat berkembang secara optimal. Adapun indikator perkembangannya yaitu mengekspresikan emosi yang sesuai dengan kondisi yang ada, mengenal tata krama dan sopan santun sesuai dengan nilai sosial budaya setempat, memahami peraturan dan disiplin. Poin indikatornya yaitu mengendalikan emosi dengan cara yang wajar, memberi dan membalas salam, mentaati aturan permainan.

\section{Kata Kunci: Keterampilan Berpidato, Metode Bercerita, Pengembangan Sosial}

\section{Pendahuluan}

Dalam Undang-Undang RI Nomor 20 Tahun 2003 Tentang Sistem Pendidikan Nasional Bab 1 Ayat 14 menjelaskan bahwa pendidikan anak usia dini adalah suatu upaya pembinaan yang ditujukan kepada anak sejak lahir sampai usia 6 tahun yang dilakukan melalui pemberian rangsangan pendidikan untuk membantu pertumbuhan dan perkembangan jasmani dan rohani agar anak memiliki kesiapan dalam memasuki pendidikan lebih lanjut. ${ }^{1}$

Perkembangan sosial emosional adalah salah satu perkembangan yang harus ditangani secara khusus, karena perkembangan sosial emosional anak harus dibina pada masa kanak-kanak awal atau biasa disebut masa pembentukan yaitu masa golden age. Pengalaman sosial awal sangatlah penting, pengalaman sosial anak sangat menentukan kepribadian anak setelah ia menjadi orang dewasa. Banyaknya pengalaman yang menyenangkan dapat mendorong anak untuk mencari dan mendorong anak untuk mempunyai sikap sosial yang baik.

Sedangkan, banyaknya pengalaman yang kurang menyenangkan pada masa kanak-kanak akan menimbulkan sikap yang tidak sehat terhadap pengalaman sosial anak, pengalaman tersebut dapat mendorong anak menjadi tidak sosial, anti sosial bahkan anak cenderung tidak percaya diri. ${ }^{2}$ Perkembangan sosial dapat pula diartikan sebagai proses belajar untuk menyesuaikan diri terhadap norma-norma kelompok, moral dan tradisi meleburkan diri menjadi satu kesatuan dan saling berkomunikasi dan kerjasama. ${ }^{3}$

Menurut Amir Faisal ciri-ciri anak yang emosionalnya berkembang secara baik adalah mereka memiliki kesabaran, mampu menahan dan mengendalikan diri, dapat menyesuaikan diri, berinisiatif, kreatif, peduli, mandiri, tanggung jawab, suka bersahabat, mampu berkomunikasi, dan mempengaruhi orang lain, memiliki impian, optimis, gigih, ulet, suka tantangan, serta

\footnotetext{
${ }^{1}$ Kemendiknas, "Peraturan Menteri Nasional Republik Indonesia Nomor 58 Tahun 2009 Tentang Standar Pendidikan Anak Usia Dini" (Yogyakarta: Bina Insane Mulia, 2010), 3. 58
}

2 Gerungan, Psikologi Sosial (Bandung: Refika Aditama, 2014), 30.

3 Ibid., 38.

el Bidayah: Journal of Islamic Elementary Education Volume 3, Nomor 1, Maret 2021 
percaya diri. ${ }^{4}$ Sedangkan menurut Zainal Aqib setiap orang mempunyai pola perkembangan emosi yang berbeda. oleh karena itu emosi anak kecil nampak berbeda dari emosi anak yang lebih tua atau orang dewasa. Ciri khas emosi anak adalah emosinya kuat, emosi yang sering tampak, emosinya bersifat sementara dan emosi anak dapat diketahui melalui perilaku anak. ${ }^{5}$ Dapat disimpulkan bahwa setiap orang mempunyai pola perkembangan emosi yang berbeda. jadi, pribadi anak sejak dini harus kita bentuk agar memiliki perkembangan emosional yang baik.

Ada beberapa indikator perkembangan sosial emosional anak usia dini yang harus dicapai dalam kegiatan pembelajaran anak usia dini yang telah ditetapkan oleh peraturan Menteri Pendidikan Nasional Republik Indonesia nomor 58 tahun 2009 tentang standar pendidikan anak usia dini sebagai berikut:

Tabel 1 Indikator Perkembangan Sosial Emosional Anak Usia Dini ${ }^{6}$

\begin{tabular}{|l|l|}
\hline Aspek & Perkembangan Sosial \\
& Emosional Anak Usia 5-6 \\
Tahun & \\
\hline Emosial & 1. Mengekspresikan emo- \\
& si yang sesuai dengan \\
& kondisi yang ada (se- \\
& nang-sedih-antusias \\
& dsb) \\
& 2. Mengenal tata krama \\
& dan sopan santun sesu- \\
& ai dengan nilai sosial \\
& budaya setempat \\
& 3. Memahami peraturan \\
& dan disiplin \\
\hline
\end{tabular}

${ }^{4}$ Amir Faisal dan Zulfana, Menyiapkan Anak Jadi Juara (Jakarta: Elex Media Komputindo, 2008), 31.

${ }^{5}$ Zainal Aqib, Belajar dan Pembelajaran di Taman Kanak-kanak (Bandung: Yrama Widya, t.t.), 40.

${ }^{6}$ Kemendiknas, “Peraturan Menteri Pendidikan Nasional Republik Indonesia Nomor 58 Tahun 2009 tentang Standar Pendidikan Anak Usia Dini," 2009.
Dari tabel di atas perkembangan menurut Peraturan Menteri Pendidikan Nasional Republik Indonesia nomor 58 tahun 2009 bahwasannya perkembangan sosial emosional anak usia 5-6 tahun dikatakan berkembang sesuai harapan jika anak mampu mengekspresikan emosi yang sesuai dengan kondisi yang ada, mengenal tatakrama dan sopan santun sesuai dengan nilai sosial budaya setempat, memahami peraturan dandisiplin. Sebagaimana yang dikemukakan Slamet Suyanto bahwa pendidikan anak usia dini bertujuan untuk mengembangkan seluruh potensi anak agar kelak dapat berfungsi sebagai manusia yang utuh sesuai falsafah suatu bangsa. $^{7}$

Stimulus yang digunakan yaitu melalui pendidikan anak usia dini seperti yang diamanatkan dalam UU No.20 Tahun 2003 tentang Sistem Pendidikan Nasional, pendidikan anak usia dini adalah suatu upaya pembinaan yang ditujukan kepada anak sejak lahir sampai dengan usia 6 tahun yang dilakukan melalui pemberian rangsangan pendidikan untuk membantu pertumbuhan dan perkembangan jasmani dan rohani agar anak memiliki kesiapan dalam memasuki pendidikan lebih lanjut. ${ }^{8}$

Menurut Kamus Besar Bahasa Indonesia (KBBI), pengertian penerapan adalah perbuatan menerapkan. Sedangkan menurut beberapa ahli berpendapat bahwa, penerapan adalah suatu perbuatan mempraktekkan suatu teori, metode, dan hal lain untuk mencapai tujuan tertentu dan untuk suatu kepentingan yang diinginkan oleh suatu kelompok atau golongan yang telah terencana dan tersusun sebelumnya.

\footnotetext{
${ }^{7}$ Slamet Suyanto, Dasar-dasar Pendidikan Anak Usia Dini (Yogyakarta: Hikayat Publishing, t.t.), 3. 8 Ibid., 2.
} 
Pengertian penerapan adalah perbuatan menerapkan. ${ }^{9}$ Sedangkan menurut beberapa ahli, penerapan adalah suatu perbuatan mempraktekkan suatu teori, metode, dan hal lain untuk mencapai tujuan tertentu dan untuk suatu kepentingan yang diinginkan oleh suatu kelompok atau golongan yang telah terencana dan tersusun sebelumnya. Dalam manajemen, penerapan dapat juga disebut dengan implementasi.

Menurut Nurdin Usman, penerapan adalah bermuara pada aktivitas, aksi, tindakan atau adanya mekanisme suatu sistem. Penerapan bukan sekedar aktivitas, tapi suatu kegiatan yang terencana dan untuk mencapai tujuan kegiatan. ${ }^{10}$ Guntur Setiawan berpendapat, penerapan adalah perluasan aktivitas yang saling menyesuaikan proses interaksi antara tujuan dan tindakan untuk mencapainya serta memerlukan jaringan pelaksana, yaitu birokrasi yang efektif. ${ }^{11}$

1. Fungsi Penerapan

Penerapan ini dapat disebut sebagai suatu proses tindakan administrasi dan politik. Pandangan ini sejalan dengan pendapat Peter $S$. Cleaves dalam bukunya Solichin Abdul Wahab, yang secara tegas menyebutkan bahwa: "a process of movingtoward a policyobjectivebymeans of administratif Ana politicalsteps".12 Secara garis besar, dikatakan bahwa fungsi penerapan itu untuk membentuk suatu hubungan yang memungkinkan tujuan-tujuan

\footnotetext{
${ }^{9}$ Peter Salim dan Yenny Salim, Kamus Bahasa Indonesia Kontemporer (Jakarta: Modern English Press, t.t.), 1598.

${ }^{10}$ Nurdin Usman, Konteks Implementasi Berbasis Kurikulum (Jakarta: Grasindo, t.t.), 70.

${ }^{11}$ Guntur Setiawan, Impelemtasi dalam

Birokrasi Pembangunan (Jakarta: Balai Pustaka, 2004), 39.

12 Solichin Abdul Wahab, Analisis Kebijakan dari Formulasi ke Implementasi Kebijaksanaan Negara (Jakarta: Bumi Aksara, 2008), 187. 60
}

ataupun sasaran-sasaran yang diwujudkan sebagai outcome hasil akhir kegiatan yang dilakukan oleh seseorang.

2. Langkah-langkah Penerapan

Menurut George Terry dan Leslie W. Rue, sebelum menerapkan atau mengimplementasikan itu, ada kegiatan yang disebut dengan merencanakan (planning) serta ada yang dinamakan dengan mengorganisasikan (organizing). ${ }^{13}$ Planning (perencanaan) ialah penetapan pekerjaan yang harus dilaksanakan oleh kelompok untuk mencapai tujuan yang digariskan.

Menurut Imam Musbikin, bercerita merupakan proses mengenalkan bentuk-bentuk emosi dan ekspresi kepada anak, misalnya marah, sedih, gembira, kesal, dan lucu. Hal ini akan memperkaya pengalaman emosinya yang akan berpengaruh terhadap pembentukan dan perkembangan kecerdasan emosionalnya. ${ }^{14}$ Maksudnya dalam cerita yang disampaikan seorang pendidik harus bisa menghayati ekspresi yang ada dalam cerita sehingga anak mampu mengerti dengan pesan yang ingin disampaikan oleh pendidik seperti marah, sedih, dan juga bahagia.

Selanjutnya Menurut Moeslichatoen, metode bercerita adalah salah satu pemberian pengalaman belajar bagi anak RA dengan tujuan Metode Bercerita sangat banyak untuk anak usia dini. Salah satunya menanamkan pesan-pesan moral yang terkandung dalam cerita yang akan mengembangkan kemampuan moral dan agama, misalnya konsep benar-salah atau konsep ketuhanan, kemudian mengembangkan kepekaan sosial-emosional anak tentang hal-hal yang terjadi di

\footnotetext{
13 George Terry dan Leslie W. Rue, Dasar-dasar Manajemen (terj.) (Jakarta: PT Bumi Aksara, 2010), 9.

14 Imam Musbikin, Buku Pintar PAUD

(Yogyakarta: Laksana, 2010), 253.
}

el Bidayah: Journal of Islamic Elementary Education Volume 3, Nomor 1, Maret 2021 
sekitarnya melalui tuturan cerita yang disampaikan. Karena melalui bercerita ada pesan moral yang ingin disampaikan. ${ }^{15}$

Adapun tujuan dari metode bercerita adalah mengembangkan kemampuan berbahasa, di antaranya kemampuan menyimak (listening), juga kemampuan dalam berbicara (speaking) Mengembangkan kemampuan berpikirnya karena dengan bercerita anak diajak untuk memfokuskan perhatian dan berfantasi mengenai jalan cerita serta mengembangkan kemampuan berpikir secara simbolik. Dari kerjasamanya dalam mengungkapkan sebuah cerita. Pada dasarnya, cerita itu dapat membantu anak dalam mengetahui karakter yang berbedabeda.

Kelebihan metode bercerita yaitu : Melatih anak untuk memfokuskan perhatian (konsentrasi) Melatih anak untuk menjadi pendengar yang baik mengem-bangkan fantasi anak terhadap hal yang tidak nyata, mengembangkan kemampuan mengingat anak terhadap hal tertentu yang disampaikan melalui tuturan secara lisan, Kekurangannya adalah sebagai berikut: Guru atau orang tua terkadang enggan untuk berekspresi dengan sebaik-baiknya karena rasa malu sehingga mempengaruhi fantasi anak, Terkadang anak merasa jenuh untuk duduk sejenak karena tidak ada media atau alat peraga yang bisa memper-tahankan konsentrasi mereka pada cerita tersebut. Kurang merangsang perkem-bangan kreativitas dan kemampuan siswa untuk mengutarakan pendapatnya, Cepat menumbuhkan rasa bosan terutama apabila penyajiannya tidak menarik. ${ }^{16}$ Dalam

${ }^{15}$ Winda Gunarti, Lilis Suryani, dan Azizah Muis, Metode Pengembangan Perilaku dan Kemampuan Dasar Anak Usia Dini (Jakarta: Universitas Terbuka, 2010), 53-55.

16 Ibid., 5-6.

el Bidayah: Journal of Islamic Elementary Education Volume 3, Nomor 1, Maret 2021 metode bercertita tentu ada kekurangan dan kelebihannya. Salah satu kelebihannya yaitu mengembangkan kemampuan mengingat anak terhadap hal tertentu yang disampaikan melalui tuturan secara lisan.

Agar metode bercerita tepat pada sasaran dalam pembelajaran, maka perlu rancangan kegiatan yang matang. Ran-cangan kegiatan bercerita yang harus dilaksanakan oleh pendidik yaitu sebagai berikut:

a. Menetapkan tujuan dan tema yang dipilih. Metode bercerita ini mempunyai tujuan dalam rangka memberi pengalaman belajar melalui cerita guru untuk mencapai tujuan pengajaran. Tujuan pengajaran itu ada 2 (dua) macam yakni memberi informasi atau menanamkan nilai-nilai sosial, moral, atau keagamaan.

b. Menetapkan bentuk bercerita yang dipilih. Setelah kita menemukan tema cerita, maka guru harus memilih bentuk-bentuk cerita seperti: bercerita menggunakan ilustrasi gambar, membaca cerita menggunakan buku gambar atau majalah, bercerita menggunakan papan flanel.

c. Menetapkan rancangan bahan dan alat yang diperlukan untuk kegiatan bercerita

d. Menetapkan rancangan langkahlangkah kegiatan bercerita

e. Menetapkan rancangan penilaian kegiatan bercerita

Perilaku sosial merupakan aktivitas dalam berhubungan dengan orang lain, baik dengan teman sebaya, guru, orang tua maupun saudara-saudaranya. Menu-rut Dini P. Daeng S sebagaimana yang dikutip oleh Novan Ardy Wiyanti dan Bamawi dalam bukunya yang berjudul format PAUD, ada empat faktor yang berpengaruh pada kemampuan anak bersosialisasi, yaitu sebagai 
berikut: Adanya kesempatan untuk bergaul dengan orang-orang di sekitarnya dari berbagaiusi, Adanya minat dan motivasi untukbergaul, Adanya bimbingan dan pengajaran dari orang lain, yang biasanya menjadi "model" bagi anak, Kemampuan sosialisasi dapat pula berkembang melalui cara "coba salah" (trial and error) yang dialami olehanak, Adanya kemampuan berkomunikasi yang baik yang dimiliki anak. $^{17}$

Menurut Hurlock sebagaimana yang dikutip oleh Masitoh, dkk dalam bukunya yang berjudul "Strategi Pembelajaran TK" mengemukakan bahwa mulai usia 2 sampai 6 tahun, anak belajar melakukan hubungan sosial dan bergaul dengan orang-orang di luar lingkungan rumah, terutama dengan anak-anak yang umurnya sebaya. Mereka belajar menyesuaikan diri dan bekerja sama dalam kegiatan bermain. Studi lanjutan tentang kelompok anak melaporkan bahwa sikap dan perilaku sosial yang terbentuk pada usia dini biasanya menetap dan hanya mengalami perubahan sedikit. ${ }^{18}$

Emosi adalah perasaan yang ada dalam diri kita, dapat berupa perasaan senang atau tidak senang, perasaan baik atau buruk. Dalam Work Book Dictionary yang dikutip oleh Ali Nugraha dan Yeni Rachmawati dalam bukunya yang berjudul "Metode Pengembangan Sosial Emosional" maka emosi didefinisikan sebagai "berbagai perasaan yang kuat" perasaan benci, takut, marah, cinta, senang, dan

\footnotetext{
${ }^{17}$ Ernawulan Syaodih dan Mubiar Agustin, Bimbingan Konseling untuk Anak Usia Dini (Jakarta: Universitas Terbuka, 2010), 223. 18 Masitoh, Stategi Pembelajaran TK (Jakarta: Universitas Terbuka, 2007), 215. 62
}

kesedihan. Macam-macam perasaan tersebut adalah gambaran dari emosi. ${ }^{19}$

Perkembangan emosional menurut Amaryllia Puspitasari yaitu kemampuan untuk mengendalikan emosi dan rasionalsecarabersamaan dengan kondisi yang tepat. ${ }^{20}$

Sedangkan menurut Daniel Goleman sebagaimana yang dikutip oleh Andreas Hartono dalam bukunya yang berjudul "EQ Parenting (Cara Praktis Menjadi Orangtua Pelatih Emas" mendifinisikan bahwa perkembangan emosional yaitu kesanggupan untuk memperhitungkan atau menyadari situasi tempat kita berada, untuk membaca emosi orang lain dan emosi kita sendiri, serta untuk bertindak dengan tepat. ${ }^{21}$ Dapat penulis simpulkan bahwa untuk bertindak dengan tepat harus membaca emosi orang lain dan emosi kita sendiri.

Menurut Riana Mashar perkembangan emosional yaitu kemampuan untuk mengendalikan, mengolah, dan mengontrol emosi agar mampu merespon secara positif setiap kondisi yang merangsang munculnya emosi-emosi ini. ${ }^{22}$ Dapat di simpulkan bahwa pentingnya mengontrol emosi agar mampu merespons secara positif.

1. Karakteristik Perkembangan Emosi Anak

Menurut hurlock bahwa karakter emosi pada anak usia dini sangat kuat pada usia 2,5-3,5 tahun dan 5,5-6,5 tahun. Beberapa ciri utama reaksi

\footnotetext{
${ }^{19}$ Ali Nugraha dan Yeni Rachmawati, Metode Pengembangan Sosial Emosional (Jakarta: Universitas Terbuka, 2007), 1-3.

${ }^{20}$ Amaryllia Puspitasari, Emotional Intelleegent Parenting (Jakarta: Elex Media Komputindo, 2009), 6.

${ }^{21}$ Andreas Hartono, EQ Parenting (Cara Praktis Menjadi Orangtua Pelatih Emos) (Jakarta: Gramedia Pustaka Utama, 2009), 8.

22 Riana Mashar, Emosi Anak Usia Dini dan Strategi Pengembangannya (Jakarta: Kencana Prenada Media Group, 2011), 60. 
emosi pada anak. Reaksi emosi anak sangat kuat, anak akan merespons suatu peristiwa dengan kadar emosi yang sama. Semakin bertambah usia anak semakin mampu memilih kadar keterlibatan emosinya, Reaksi emosi sering muncul pada setiap peristiwa dengan cara yang diinginkannya.

2. Faktor yang Mempengaruhi Emosi Anak

Hurlock dan Lazarus menyatakan bahwa perkembangan emosi anak dipengaruhi oleh dua faktor penting yaitu: adanya proses maturation atau kema-tangan dan faktor belajar. ${ }^{23}$ Yang disebut dengan Maturation yaitu kemajuan pertumbuhan yang normal ke arah kematangan dan kedewasaan. Dapat disimpulkan bahwa proses kematangan dan faktor belajar mempengaruhi perkem-bangan emosi anak. Dikatakan emosinya berkembang dengan baik apabila proses maturation atau kematangan dan faktor belajarnya juga berkembang dengan baik.

Riana Mashar dalam bukunya yang berjudul "Emosi Anak Usia Dini dan Strategi Pengembangannya" menyatakan bahwa tingkah laku seseorang ditentukan oleh lingkungan, apa yang dialami dan dipelajari dalam kehidupan sehari-hari lebih menentukan tingkah laku dan pola tanggapan emosi.

3. Fungsi dan Peranan EmosiAnak

Merupakan bentuk komunikasi se-hingga anak dapat menyatakan segala kebutuhan dan perasaannya pada orang lain. Biasanya anak mengekspesikan sakit dan marah dengan menangis. Emosi berperan dalam mempengaruhi kepribadian dan penyesuaian diri anak dengan lingkungan sosialnya, seperti: Tingkah laku emosi anak yang ditampilkan meru-

\footnotetext{
${ }^{23}$ Elizabeth B. Hurlock, Perkembangan Anak (Edisi keenam) (Jakarta: Erlangga, 2000), 21428.
} el Bidayah: Journal of Islamic Elementary Education Volume 3, Nomor 1, Maret 2021 pakan sumber penilaian lingkungan sosial terhadap dirinya. Emosi menyenangkan atau tidak menyenangkan dapat mempengaruhi interaksi sosial anak melalui reaksi-reaksi yang ditampilkan lingkungannya.

4. Ciri-ciri Perkembangan Emosional Anak

Adapun ciri-ciri anak yang memiliki perkembangan emosi sebagai berikut: mampu memotivasi diri sendiri, mampu menahan dan mengendalikan diri, dapat menyesuaikan diri, berinisiatif dan kreatif. Mempunyai sikap peduli mandiri dan juga bertanggung jawab suka bersahabat mampu berkomunikasi dan mengarahkan orang lain

a. Memiliki impian

b. Optimis,ulet dan gigih serta percaya diri. $^{24}$

Perkembangan emosi ini sangat penting bagi anak sebagai bekal dalam kehidupannya. Anak yang memiliki perkembangan emosi baik mereka lebih sukses, dibanding mereka yang mempunyai kecerdasan intelektual saja.

5. Tingkat Pencapaian Perkembangan Sosial Emosional Anak Usia 5-6

Menurut undang-undang Nomor 20 Tahun 2003 tentang Sistem Pendidikan Nasional Pasal 1 angka 14 menyatakan bahwa Pendidkan Anak Usia Dini (PAUD) adalah suatu upaya pembinaan yang ditujukan kepada anak sejak lahir sampai dengan usia enam tahun yang dilakukan melalui pemberian rangsangan pendidikan untuk membantu pertumbuhan dan perkembangan jasmani dan rohani agar anak memiliki kesiapan dalam memasuki pendidikan lebih lanjut. ${ }^{25}$

\footnotetext{
${ }^{24}$ Faisal dan Zulfana, Menyiapkan Anak Jadi Juara, 31.

${ }^{25}$ Kemendiknas, "Peraturan Menteri Pendidikan Nasional Republik Indonesia Nomor 58 Tahun 2009 tentang Standar Pendidikan Anak Usia Dini," 1.
} 
Peraturan Menteri Pendidikan Nasional Republik Indonesia nomor 58 tahun 2009 bahwasannya perkembangan sosial emosional anak usia 5-6 tahun dikatakan berkembang sesuai harapan jika anak mampu mengekspresikan emosi yang sesuai dengan kondisi yang ada, mengenal tata krama dan sopan santun sesuai dengan nilai sosial budaya setempat, memahami peraturan dan disiplin. Pentingya mengembangkan sikap sosial emosional anak sejak usia dini. ${ }^{26}$

\section{Metode}

Penelitian ini merupakan penelitian deskriptif dengan pendekatan kualitatif. Dimana pada penelitian deskriptif dilakukan analisis yang mengacu pada data dengan memanfaatkan teori yang ada. Data didapat setelah diterapkan metode bercerita dalam pembelajaran. Data yang diolah berisi tentang perkembangan sosial emosional anak usia dini.

Penelitian ini dilaksanakan di Pendidkan RA Ihyaul Islam yang berdiri pada Tahun 2003 yang di dirikan oleh Ibu Syamsiyah dibawah Yayasan Ihyaul Islam. Lembaga RA Ihyaul Islam berlokasi di Desa Prasi Kecamatan Gading dengan jumlah siswa seluruhnya 50 anak. Terdiri dari siswa laki-laki 17 dan siwa perempuan 33 terbagi menjadi siswa kelompok A berjumlah 19 anak, sedangkan siswa kelompok B berjumlah 31 anak. Lembaga RA Ihyaul Islam mempunyai tenaga pendidik berjumlah 5 orang dan tenaga kependidikan 1 orang.

Secara umum letak geografis RA Ihyaul Islamcukup strategis dan mudah

\footnotetext{
${ }^{26}$ Ibid, 13.
}

64 dijangkau dengan menggunakan alat transportrasi umum maupun pribadi yang mana letaknya berada di jalan Gading No.54 Dusun Selatan RT007/ RW016. Desa Prasi Kecamatan Gading Kabupaten Probolinggo Provinsi Jawa Timur. serta jauh dari pusat pembelanjaan atau supermarket maupun pasar tradisional dan keadaan sangat kondusif dalam pelaksanan pembelajaran sehingga anak merasa nyaman dalam melaksanakan prosesbelajar. Teknik pengumpulan data menggunakan observasi, wawancara dan dokumentasi.

\section{Temuan dan Pembahasan Temuan penelitian}

Penerapan metode bercerita dalam meningkatkan perkembangan sosial emosional anak di RA Ihyaul Islam Prasi Gading. Penerapan merupakan suatu tindakan atau pelaksanaan dari suatu rencana yang sudah di susun secara terperinci. Realisasi dari pada sosial emosional anak dalam kegiatan sehari-hari di kelas terdiri dari sikap yang bermacam-macam, ada yang positif dan negatif, mulai dari sifat anak yang dapat disukai teman-teman dan gurunya sampai pada sifat perusak yang dapat membuat keadaan kelas menjadi gaduh.

Sehingga perlu adanya langkahlangkah yang dilakukan seorang pendidik dalam menerapkan metode bercerita terhadap perkembangan sosial emosional anak usia dini di RA Ihyaul Islam.

Berdasarkan hasil wawancara penulis dengan Batlaifah, S.Pd. bahwasannya guru di Pendidikan Anak Usia

el Bidayah: Journal of Islamic Elementary Education Volume 3, Nomor 1, Maret 2021 
Dini RA Ihyaul Islam telah menetapkan tujuan dan tema sesuai dengan yang direncanakan. Tujuan dan tema hendaknya menanamkan nilai-nilai sosial, moral, atau keagamaan. Demikian juga guru menyiapkan tujuan dan tema harus ada kedekatan hubungan dengan kehidupan anak di dalam keluarga, sekolah, atau di luar sekolah. Serta tema itu harus menarik dan memikat perhatian anak dan menantang anak untuk menanggapi, menggetarkan perasaan, serta menyentuh nuraninya.

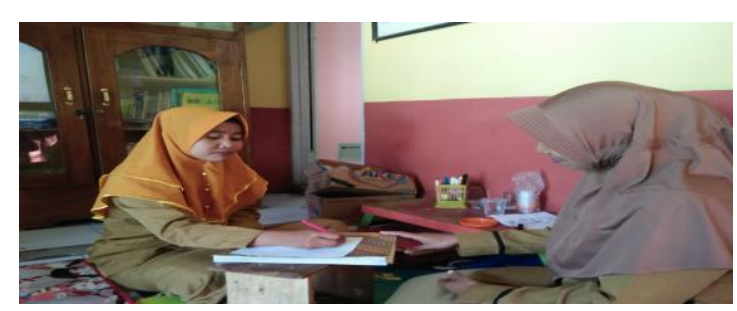

Gambar 1 Wawancara peneliti terhadap guru RA Ihyaul Islam

Berdasarkan hasil wawancara di atas dapat di katakan bahwasanya menetapkan tujuan dan tema yang dipilih seperti tema kisah nabi musa penggem-bala kambing untuk kegiatan bercerita sesuai yang direncanakan dapat mengembangkan sosial emosional anak usia dini serta menanamkan nilai-nilai yg terkandung dalam isi cerita tersebut dengan menerapkannya di sekolah maupun di rumah.

1. Menetapkan Bentuk Buku Cerita Yang di Pilih

Selanjutnyapada hari selasa tang-gal 20 Februari 2020 peneliti mengadakan wawancara untuk yang kedua kali yaitu guru RA Ihyaul Islam juga sebagai informan ke-2 yaitu ibu Sholehatun Nisak, S.pd. disamping menetapkan tujuan dan tema langkah kedua yaitu mene-tapkan bentuk buku cerita yang akan di pakai dalam kegiatan bercerita.
Berikut hasil wawancara penulis dengan ibu Batlaifah, S.Pd. bahwasannya guru di Pendidikan RA Ihyaul Islam telah menetapkan bentuk bercerita yang dipilih sesuai dengan tema yang telah ditetapkan sebelumnya. Bentuk-bentuk yang bisa dipilih missalnya bercerita dengan membaca langsung dari buku cerita, yang menggunakan ilustrasi gambar, Hal ini penting dilakukan karena akan memberikan ketertarikan dengan adanya bentuk gambar-gambar yang lucu untuk menarik perhatian anak.

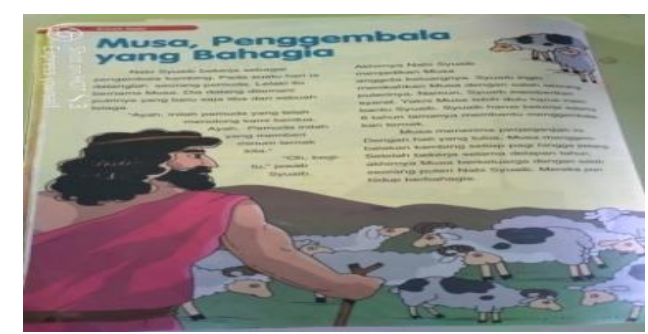

Gambar 2 Gambaran Cerita di Buku Pelajaran

Berdasarkan hasil wawancara penulis di atas dapat dikatakan bahwasanya menetapkan bentuk bercerita yang dipilih sesuai dengan tema yang telah ditetapkan itu sangat penting karena dengan adanya ilustrasi gambar memberikan ketertarikan dalam pembelajaran bercerita.

2. Menetapkan Bahan dan Alat Yang Di Perlukan

Untuk Kegiatan Bercerita Sesuai Dengan Yang Di Rencanakan. Selanjutnya pada hari rabu tanggal 23 Februari 2020 peneliti mengadakan wawancara lagi di lembaga RA. Ihyaul Islam untuk mengetahui bahan dan alat apa yang di gunakan untuk kegiatan metode Bercerita. Senada dengan hasil wawancara penulis dengan Ibu Batlaifah, S.Pd. bahwasannya guru di Pendidikan Anak 
Usia Dini RA. Ihyaul Islam telah menetapkan bahan dan alat yang diperlukan untuk kegiatan bercerita sesuai dengan yang direncanaka seperti buku cerita. Hendaknya buku cerita yang dipakai dapat menarik perhatian anak. Guru cukup memperlihatkan gambar dalam buku itu pada waktu bercerita.

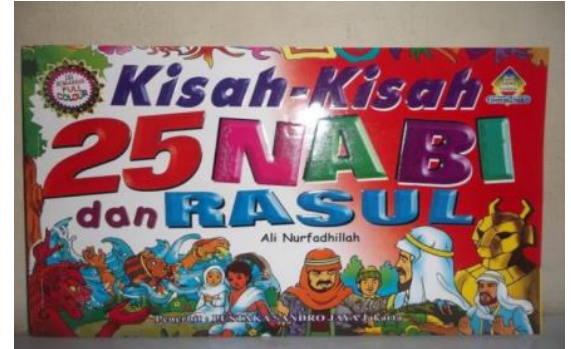

Gambar 3 Bahan atau buku panduan yang di pakai bercerita

Berdasarkan hasil wawancara di atas penulis dapat mengatakan bahwa di Pendidikan Anak Usia Dini RA. Ihyaul Islam gurunya telah menetapkan bahan dan alat yang diperlukan salah satunya dengan menggunakan buku cerita kisah para nabi dan rosul untuk kegiatan bercerita sesuai dengan yang direncanakan sehingga dapat mengembangkan sosial emosional anak di Ra Ihyaul Islam.

3. Sebelum Bercerita Mengatur Tempat Duduk Terlebih Dahulu

Selanjutnya peneliti mengadakan wawancara kembali pada hari kamis tanggal 27 Februari 2020, untuk mengetahui apakah guru mengatur tempat duduk anak terlebih dahulu sebelum memulai kegiatan berceirta di mulai. Senada dengan hasil wawancara penulis dengan ibu Sholehatun Nisak, S.Pd. bahwasannya guru di RA Ihyaul Islam, mengatur tempat duduk anak terlebih dahulu dan panduan untuk mengkomunikasikan tata tertib yang harus di patuhi. Mengatur tempat duduk merupakan hal yang cukup penting, karena posisi tempat duduk yang tepat dapat membuat kegiatan bercerita tidak melelahkan. Apabila kegiatan bercerita dilakukan dalam kelompok besar, maka memerlukan tempat yang lebih luas dibanding dengan kelompok kecil. Setting yang dipilih yaitu anak duduk dengan duduk dikursi.

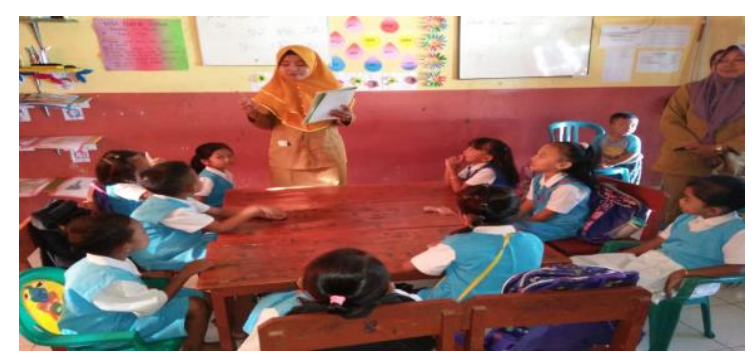

Gambar 4 Posisi duduk anak ketika mendengarkan cerita guru

Berdasarkan hasil wawancara di atas penulis dapat mengatakan bahwa di RA Ihyaul Islam, gurunya telah mengatur tempat duduk anak terlebih dahulu sebelum mulai bercerita, karena tempat duduk anak sangat penting demi kenyamanan anak untuk mendengarkan guru bercerita sesuai dengan tema yang telah di tentukan oleh guru.

4. Membuka Kegiatan Bercerita

Sesuai Dengan Tujuan dan Tema Yang Sudah Di Tetapkan Pada tanggal 28 Februari 2020 hari jumat peneliti juga mengadakan wawancara kepada ibu Sholehatun Nisak, S.Pd. sebagai informen ke 2 untuk menanyakan apakah kegiatan bercerita sesuai dengan tema dan tujuannya. Senada dengan hasil wawancara penulis dengan Sholehatun Nisak, S.Pd. bahwasannya guru telah membuka kegiatan bercerita sesuai dengan tujuan dan tema yang sudah ditetapkan. Membuka kegiatan bercerita dilakukan semenarik mungkin agar anak tertarik untuk mendengarkan 
seperti dengan mem-berikan contoh bagaimana cara nabi ibrohim ketika menyembelih putranya nabi ismail, dengan praktek menyembelih binatang qurban dimana guru menyuruh satu anak yang berani untuk kedepan menjadi kambing yang akan di sembelih dengan begini anak merasa senang dan antusia untuk mendengarkan cerita guru.

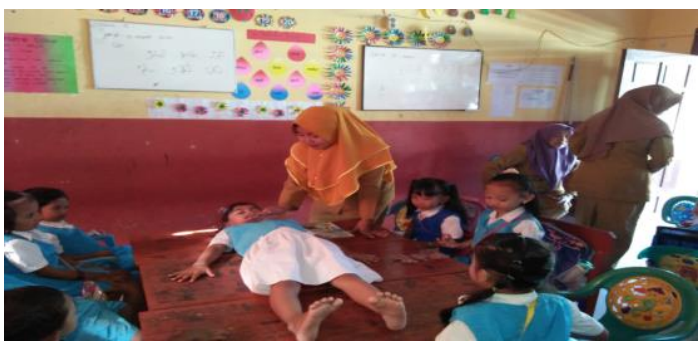

Gambar 5 Guru mempraktekkan dengan menjadikan salah satu murid sebagai contoh

Berdasarkan hasil wawancara di atas penulis dapat mengatakan bahwa di RA Ihyaul Islam gurunya telah melakukan pembukaan kegiatan bercerita sesuai dengan tujuan dan tema yang sudah ditetapkan.

5. Pengembangan Cerita yang Di

Tuturkan Guru Sesuai Tujuan dan

Tema Yang Sudah di Tetapkan

Selanjutnya pada hari sabtu tanggal 29 Februari 2020 peneliti mengadakan wawancara lagi dengan ibu guru Batlaifah, S.Pd. menayakan bagaimana cara penyampaian metode bercerita agar anak mampu mempraktekkan di ling-kungan rumah ataupun di sekolah sesuai tujuan dan tema yang sudah di tetapkan. Senada dengan hasil wawancara penulis dengan ibu Batlaifah, S.Pd. bahwasannya guru harus mengembangkan cerita sesuai tujuan dan tema yang sudah ditetapkan serta menyajikan fakta-fakta di sekitar kehidupan anak, seperti menyayangi binatang, tidak boleh menyiksa binatang sebab binatang juga adalah makhluk ciptaan Allah yang juga butuh akan kasih sayang.

Berdasarkan hasil wawancara di atas penulis dapat mengatakan bahwa gurunya telah melakukan pengembangan cerita sesuai tujuan dan tema yang sudah ditetapkan serta menyajikan fakta-fakta di sekitar kehidupan anak baik di rumah ataupun di sekolah.

6. Menetapkan Teknik Bertutur Yang Dapat Menggetarkan Perasaan Anak

Merupakan Bagian Yang Terkandung Dalam Tujuan dan Tema Yang Sudah Di Tetapkan Pada hari senin tanggal 2 Maret 2020 peneliti mengadakan wawancara lagi dengan ibu Sholehatun Nisak, S.Pd. untuk bertanya apakah tekhnik bertutur kata dalam bercerita juga merupakan tujuan yang harus di capai agar anak merasa antusia dalam mengdengarkan cerita tersebut sesuai dengan tema yang sudah di tetapkan. Senada dengan hasil wawancara penulis dengan Ibu Batlaifah, S.Pd. Bahwasannya guru telah melakukan teknik bertutur yang dapat menggetarkan perasaan anak dengan cara memberikan gambaran anak penyayang binatang yang disayang oleh Allah SWT. Kemudian guru menggambarkan anak yang tidak menyayangi binatang. Selanjutnya guru merancang upaya untuk menyentuh hati nurani anak-anak perlunya menyayangi binatang, serta bertutur yang dapat menyentuh hati nurani anak-anak untuk menyayangi binatang ciptaan Allah. 


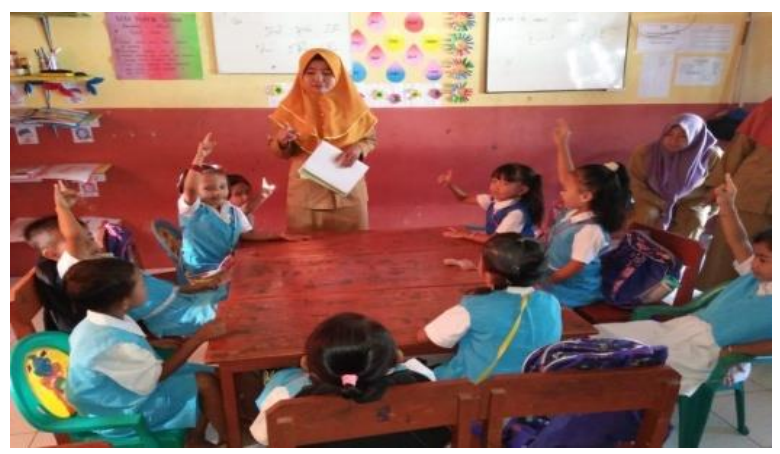

Gambar 6 Guru bercerita dengan bahasa yang santun

Berdasarkan hasil wawancara di atas dapat penulis simpulkan bahwa di Pendidikan Anak Usia Dini RA Ihyaul Islam, gurunya telah melakukan teknik bertutur yang dapat menggetarkan perasaan anak merupakan bagian yang terkandung dalam tujuan dan tema yang sudah ditetapkan.

7. Mengajukan Pertanyaan Pada Akhir

Kegiatan Bercerita

Pada tanggal 4 Maret 2020 peneliti ke lembaga RA Ihyaul Islamuntuk melakukan wawancara yang terakhir dengan ibu guru Sholehatun Nisak Spd selaku guru pendamping di kelompok A.

Berikut hasil wawancara penulis denganIbu Sholehatuh Nisak, S.Pd. bahwasannya guru harus mengajukan pertanyaan pada akhir kegiatan bercerita yang memberi petunjuk seberapa besar perhatian dan tanggapan anak terhadap isi cerita.

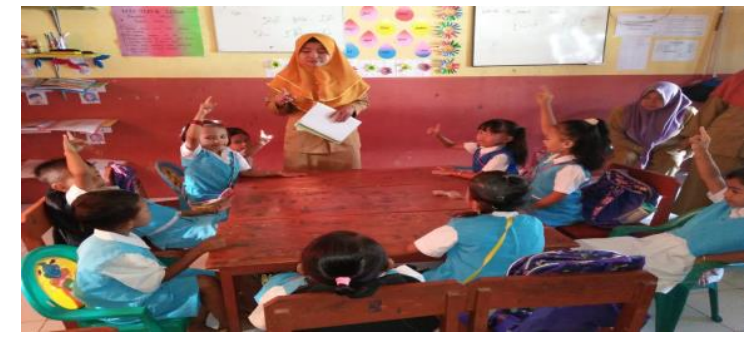

Gambar 7 Guru mengajukan pertanyaan pada akhir kegiatan

Berdasarkan hasil wawancara di atas penulis dapat mengatakan bahwa gurunya telah mengajukan pertanyaan pada akhir kegiatan bercerita yang memberi petunjuk seberapa besar perhatian dan tanggapan anak terhadap isi cerita.

Selanjutnya hasil observasi penulis tentang hasil perkembangan sosial emosional anak diperoleh bahwa perkembangan sosial emosional Putri, Nadin dan Feby hasilnya paling tinggi yaitu 9 dengan kriteria Berkembang Sesuai Harapan (BSH). Senada dengan hasil wawancara penulis dengan Ibu Batlaifah, S.Pd. bahwasannya perkembangan sosial emosional Putri, Nadin dan Feby Berkembang Sesuai Harapan (BSH) namun terkadang masih suka moody.

Sedangkan hasil observasi yang penulis lakukan bahwa perkembangan sosial emosional ilham, alya, zahra, thoriq, anin, amel, raka, aka, hafis, nayla, riska, muhlisin, alwan, rofi, dan saif hasilnya paling rendah yaitu dengan kriteria Mulai Berkembang (MB). Senada dengan hasil wawancara penulis dengan Ibu Sholehatun Nisak, S.Pd. bahwasannya perkembangan sosial emosional mereka Mulai Berkembang (MB).

Jadi observasi akhir perkembangan sosial emosional anak keseluruhan dalam satu kelas maka kriterianya Belum Berkembang (BB), perkembangan sosial emosional anak tidak mengalami perubahan yang signifikan. Kemudian dapat penulis katakan bahwasannya penggunaan langkah- langkah penerapan metode bercerita yang tepat dan benar belum dapat mengembangkan sosial emosional anak secara optimal di RA Ihyaul Islam Prasi Gading. Dilihat dari observasi akhir bahwa:

1. Anak yang mengekspresikan emosi yang sesuai dengan kondisi yang ada (senang, sedih, antusias, dsb) poin mengendalikan emosi dengan cara yang wajarada 10 anak Berkembang Berkembang (BB), 6 anak mulai berkembang (MB),dan 3 anak berkembang sesuai harapan, serta 
Berkembang Sangat Baik (BSB) 0 anak.

2. Mengenal tatakrama dan sopan santun sesuai dengan nilai budaya setempat poin memberi dan membalas salam ada 0 anak Belum Berkembang (BB), 10 anak Mulai Berkembang (MB), 9 anak berkembang sesuai harapan (BSH), dan 0 anak berkembang sangat baik (BSB).

3. Memahami peraturan dan disiplin poin mentaati aturan permainan ada 10 anak Belum Berkembang (BB), 7 anak Mulai Berkembang (MB), 3 anak Berkembang Sesuai Harapan (BSH), dan 0 anak belum Berkembang Sangat Baik (BSB).

\section{Pembahasan}

Penelitian ini di lakukan di lembaga RA Ihyaul Islam Prasi Gading, yang mana lembaga RA Ihyaul Islam cukup strategis dam mudah dijangkau dengan menggunakan alat transportrasi umum maupun pribadi, yang mana letaknya berada di jalan Argopuro No.540 Dusun Selatan RT007/RW016 Desa Prasi Kecamatan Gading Kabupaten Probolinggo Provinsi Jawa Timur. serta jauh dari pusat pembelanjaan atau supermarket maupun pasar tradisional dan keadaan sangat kondusif dalam pelaksanan pembelajaran sehingga anak merasa nyaman dalam melaksanakan prosesbelajar.

Dari hasil observasi dan wawancara tersebut, maka penulis dapat simpulkan bahwa sosial emosional anak belum dapat berkembang secara optimal meskipun dengan menggunanakan penerapan metode bercerita yang benar dan tepat, meskipun pendidik atau guru sudah melakukan langkah-langkah cara menerapkan metode bercerita yang tepat dari cara guru menetapkan tema, bentuk buku cerita, alat yang di perlukan untuk bercerita serta penuturan kata yang sehingga bisa lebih menarik anak untuk bisa membawa anak bisa fokus dalam mendengarkan cerita tersebut. Hal ini belum bisa di katakan berhasil sebab anak lebih mementingkan emosinya dan blm cukup sabar dalam mendengarkan cerita guru sehingga pembelajaran bercerita ini tidak kondusif. Oleh karena itu perlu adanya metode keteladanan dan pembiasaanpembiasaan yang dilakukan guru dalam setiap kegiatan bercerita yang diterapkan sesuai dengan tiga indikator yang ditentukan dalam meningkatkan perkembangan sosial anak usia 5-6 tahun yaitu dengan mengekspresikan emosi yang sesuai dengan kondisi yang ada (senang, sedih, antusias, dsb), mengenal tata krama dan sopan santun sesuai dengan nilai sosial budaya setempat, memahami peraturan dan disiplin dengan poin mengendalikan emosi dengan cara yang wajar, memberi dan membalas salam, mentaati aturan permainan.

\section{Kesimpulan}

Berdasarkan hasil pengolahan dan analisis data hasil penelitian yang penulis lakukan maka dapat disimpulkan bahwa penerapan metode bercerita untuk meningkatkan perkembangan sosial emosional anak di RA Ihyaul Islam Prasi Gadingsudah terlaksana dengan baik, dengan menggunakan langkah-langkah sebagai berikut: Menetapkan tujuan dan tema yang dipilih untuk kegiatan bercerita, Menetapkan bentuk bercerita yang dipilih, Menetapkan bahan dan alat yang diperlukan untuk kegiatan bercerita sesuai dengan yang direncanakan, Sebelum mulai bercerita mengatur tempat duduk anak terlebih dahulu, Mengajukan pertanyaan pada akhir kegiatan bercerita.

Perkembangan sosial emosional anak berdasarkan hasil observasi dapat disimpulkan bahwa kelas kelompok A 
secara keseluruhan kriterianya Belum Berkembang (BB) dengan total hasil 116, ada 6 anak dengan kriteria Mulai Berkembang (MB), kemudian ada 3 anak dengan kriteria Berkembang Sesuai Harapan (BSH) dari 19 anak. Maka penulis dapat simpulkan bahwa sosial emosional anak belum dapat berkembang sangat baik secara optimal dengan adanya penerapan metode bercerita yang benar dan tepat serta, keteladanan dan pembiasaan-pembiasaan yang dilakukan guru dalam setiap kegiatan bercerita yang diterapkan sesuai dengan tiga indikator yang ditentukan dalam pengembangan sosial emosional anak usia 5-6 tahun yaitu:

a. Mengekspresikan emosi yang sesuai dengan kondisi yang ada (senang, sedih, antusias, dsb)

b. Mengenal tata krama dan sopan santun sesuai dengan nilai sosial budaya setempat

c. Memahami peraturan dan disiplin,

Peranan yang dilakukan guru pun sudah sangat baik, karena guru telah memahami bagaimana penerapan metode bercerita yang tepat dan benar, dengan ditandai adanya kemampuan guru mampu memberikan teladan agar anak dapat menghormati orang lain, guru dapat membiasakan anak untuk memahami aturan dan disiplin, dan guru selalu mengupayakan program makan bersama dan bercerita untuk menumbuhkan sikap disiplin juga selalu membuat kegiatan sosial yang diikuti oleh semua anak sewaktuwaktu.

Berdasarkan penelitian yang telah penulis lakukan, maka dapatlah penulis memberikan saran-saran demi kemajuan Pendidikan Anak Usia Dini di RA Ihyaul IslamPrasi Gading sebagai berikut:

1. Diharapkan kepada Pendidikan Anak Usia Dini di RA Ihyaul Islam
Prasi Gading untuk dapat memperhatikan guru dalam menerapkan metode bercerita dalam meningkatkan perkembangan sosial emosional anak khususnya dan menumbuhkannya lebih besar lagi demi kehidupan anak di masyarakat kelak, serta melengkapi alat-alat pengajaran demi kelancaran proses belajar mengajar.

2. Kepada guru agar memberikan motivasi bagi pesertadidik, untuk meningkatkan rasa sosial emosionalnya baik di lingkungan sekolah maupun di lingkungan rumah. Dengan cara melatih kesabaran dan bisa mengendalikan emosinya secara wajar.

\section{Daftar Pustaka}

Abdul Wahab, Solichin. Analisis

Kebijakan dari Formulasi ke Implementasi Kebijaksanaan Negara. Jakarta: Bumi Aksara, 2008.

Aqib, Zainal. Belajar dan Pembelajaran di Taman Kanak-kanak. Bandung: Yrama Widya, t.t.

Faisal, Amir, dan Zulfana. Menyiapkan Anak Jadi Juara. Jakarta: Elex Media Komputindo, 2008.

Gerungan. Psikologi Sosial. Bandung: Refika Aditama, 2014.

Gunarti, Winda, Lilis Suryani, dan Azizah Muis. Metode Pengembangan Perilaku dan Kemampuan Dasar Anak Usia Dini. Jakarta: Universitas Terbuka, 2010.

Hartono, Andreas. EQ Parenting (Cara Praktis Menjadi Orangtua Pelatih Emos). Jakarta: Gramedia Pustaka Utama, 2009.

Hurlock, Elizabeth B. Perkembangan Anak (Edisi keenam). Jakarta: Erlangga, 2000.

Kemendiknas. "Peraturan Menteri Nasional Republik Indonesia 
Nomor 58 Tahun 2009 Tentang

Standar Pendidikan Anak Usia

Dini." Yogyakarta: Bina Insane

Mulia, 2010.

Mashar, Riana. Emosi Anak Usia Dini dan Strategi Pengembangannya. Jakarta: Kencana Prenada Media Group, 2011.

Masitoh. Stategi Pembelajaran TK. Jakarta: Universitas Terbuka, 2007.

Musbikin, Imam. Buku Pintar PAUD. Yogyakarta: Laksana, 2010.

Nugraha, Ali, dan Yeni Rachmawati. Metode Pengembangan Sosial Emosional. Jakarta: Universitas Terbuka, 2007.

Puspitasari, Amaryllia. Emotional Intelleegent Parenting. Jakarta: Elex Media Komputindo, 2009.

Salim, Peter, dan Yenny Salim. Kamus Bahasa Indonesia Kontemporer. Jakarta: Modern English Press, t.t.

Setiawan, Guntur. Impelemtasi dalam Birokrasi Pembangunan. Jakarta: Balai Pustaka, 2004.

Suyanto, Slamet. Dasar-dasar Pendidikan Anak Usia Dini. Yogyakarta: Hikayat Publishing, t.t.

Syaodih, Ernawulan, dan Mubiar Agustin. Bimbingan Konseling untuk Anak Usia Dini. Jakarta: Universitas Terbuka, 2010.

Terry, George, dan Leslie W. Rue. Dasardasar Manajemen (terj.). Jakarta: PT Bumi Aksara, 2010.

Usman, Nurdin. Konteks Implementasi Berbasis Kurikulum. Jakarta: Grasindo, t.t. 